JURNAL ILMIAH AGRINECA

ISSN : 2721-074X (Online) - 2301-6698 (Print)

Available on : http://ejournal.utp.ac.id/index.php/AFP/index

This is Under CC BY SA Licence

\title{
PENGARUH MACAM PUPUK ORGANIK PADAT DAN INTERVAL PEMBERIAN PUPUK ORGANIK CAIR PADA PERTUMBUHAN DAN HASIL CABAI RAWIT
}

\section{Effect Kind of Solid Organic Fertilizer and Interval of Liquid Organic Fertilizer Application on Growth and Yield of Cayenne Pepper}

\author{
Daryanti*, Tyas Soemarah K.D, Muharram Indrawan, Teguh Supriyadi \\ Program Studi Agroteknologi, Fakultas Pertanian, Universitas Tunas Pembangunan \\ Jl. Balekambang lor No. 1 Manahan Surakarta \\ *Corresponden author : dyanti_utp@yahoo.co.id
}

\begin{abstract}
Cayenne pepper was a vegetable needed in the daily consumption of people in Indonesia. Efforts to increase the production of cayenne pepper include fertilization. The purpose of this study was to determine the effect of various kinds of organic fertilizer and the interval of liquid organic fertilizer on the growth and yield of cayenne pepper. This study used polybags in plastic houses, from January to May 2019 in Bangsri Village, Karangpandan District, Karanganyar Regency with a height of 450 MASL with Grumosol soil types. This research used a factorial method with the basic design of a Completely Randomized Design (CRD) consisting of 2 treatment factors and is repeated 3 times. The first factor was the type of organic fertilizer $(M)$ consisting of 3 levels, MO = Soil without organic fertilizer (control), $M 1=$ Soil and Blotong Fertilizer (ratio 1: 1), M2 = Petroganic Soil and Fertilizer (ratio 1: 1). The second factor was the interval of adduction liquid organic fertilizer $(P)$ consisting of 3 levels, $P O=$ Without the adduction of $P O C$ (liquid organic fertilizer) (control), $P 1=$ adduction $P O C$ every 7 days, $P 2=$ adduction POC every 14 days. The use of organic blotong or Petroganik fertilizer mixed with soil with a ratio of 1: 1 accompanied by the administration of POC Nasa every 14 days produces the highest number and weight of fruit.
\end{abstract}

Keywords: blotong fertilizer, petroganik, liquid organic fertilizer interval aplication,cayenne pepper

\begin{abstract}
ABSTRAK
Cabai rawit merupakan sayuran yang banyak dibutuhkan dalam konsumsi sehari-hari masyarakat di Indonesia. Upaya untuk meningkatkan produksi cabai rawit diantaranya melalui pemupukan. Penelitian ini bertujuan untuk mengetahui pengaruh macam pupuk organik dan interval pemberian pupuk organik cair terhadap pertumbuhan dan hasil cabai rawit. Penelitian ini menggunakan polibag di rumah plastik, pada bulan Januari sampai Mei 2019 di Desa Bangsri, Kecamatan Karangpandan, Kabupaten Karanganyar dengan ketinggian tempat 450 meter diatas permukaan laut dengan jenis tanah Grumosol. Penelitian ini menggunakan metode faktorial dengan rancangan dasar Rancangan Acak Lengkap (RAL) yang terdiri dari 2 faktor perlakuan dan diulang 3 kali. Factor pertama yaitu macam pupuk organic (M) terdiri dari 3 taraf, M0 $=$ Tanah tanpa pupuk organik (kontrol), M1 = Tanah dan Pupuk Blotong (dengan rasio 1:1), M2 = Tanah dan Pupuk Petroganik (dengan rasio 1:1). Faktor kedua yaitu interval pemberian pupuk organik cair (P) terdiri dari 3 taraf, $\mathrm{P} 0=$ Tanpa pemberian POC (pupuk organik cair) (kontrol), $\mathrm{P} 1=$ Pemberian POC setiap 7 hari sekali, P2 = Pemberian POC setiap 14 hari sekali. Penggunaan pupuk organic blotong atau Petroganik yang dicampurkan dengan tanah dengan rasio 1:1 disertai dengan pemberian POC Nasa 14 hari sekali menghasilkan jumlah dan berat buah yang paling tinggi.

Kata kunci : pupuk blotong, Petroganik, interval POC , cabai rawit
\end{abstract}


ISSN : 2721-074X (Online) - 2301-6698 (Print)

Available on : http://ejournal.utp.ac.id/index.php/AFP/index

This is Under CC BY SA Licence

\section{PENDAHULUAN}

Cabai rawit merupakan salah satu jenis sayuran yang banyak dibutuhkan dalam konsumsi sehari-hari masyarakat di Indonesia. Cabai rawit digunakan untuk memberikan cita rasa pedas yang ditambahkan pada suatu masakan atau disajikan dalam bentuk sambal. Kegunaan cabai yang tidak dapat digantikan oleh komoditas lainnya dan sifat buah cabai yang tidak tahan lama membuat komoditas ini harus tersedia setiap saat. Itulah sebabnya permintaan dan kebutuhan cabai selalu tinggi. Cabai merupakan komoditas pertanian yang harganya seringkali mengalami fluktuasi. Saat panen raya, harga cabai bisa sangat rendah. Sebaliknya, pada saat pasokan menurun, harga cabai bisa melambung tinggi.

Produksi cabai rawit nasional pada periode 2014-2018 terus meningkat seiring dengan tingginya kebutuhan akan buah ini. Pada tahun 2014, produksi cabai rawit mencapai 800,473 ton dengan luas panen 134.882 Ha. Pada tahun 2018, produksi cabai rawit nasional mencapai 1.323.200 ton dengan luas panen 171.690 Ha (Anonim, 2019).

Dalam budidaya cabai rawit, berbagai metode bisa dilakukan untuk dapat mencapai hasil panen yang tinggi dan bermutu baik, salah satunya adalah dengan pemupukan. Pemupukan bertujuan untuk menambah unsur hara dalam tanah yang dibutuhkan untuk pertumbuhan dan perkembangan tanaman. Penggunaan pupuk an organic mampu meningkatkan produksi tanaman dengan cepat tetapi di sisi lain bisa menimbulkan dampak negative pencemaran lingkungan dan inefisiensi pemupukan (Ali, Hosir, \& Nurlina, 2017). Penggunaan pupuk anorganik secara terus menerus dan berlebihan dapat mengakibatkan tanah menjadi keras dan produktivitas jangka panjang akan menurun.

Untuk mengurangi penggunaan pupuk anorganik, perlu digunakan pupuk organik. Sutedjo, M.M (2010) menyatakan peran pupuk organic dapat memperbaiki kesuburan kimia, fisik dan biologis tanah. Lebih lanjut dinyatakan Hardjowigeno (2010), selain menambah unsur hara, pupuk organik dapat memperbaiki struktur tanah, meningkatkan kapasitas tukar kation, meningkatkan kemampuan tanah menahan air dan meningkatkan kegiatan biologis tanah.

Berbagai macam pupuk organic bisa diaplikasikan untuk tanaman cabai rawit, ada yang berbentuk padat, ada pula yang berbentuk cair. Pupuk organic padat diaplikasikan dengan cara dicampurkan dengan tanah, sedangkan pupuk organic cair ada yang diaplikasikan dengan cara disiramkan ke tanah di sekitar perakaran tanaman atau disemprotkan ke tubuh tanaman. Unsur hara yang terkandung dalam pupuk organic cair lebih mudah diserap oleh tanah dan tanaman karena unsure hara sudah dalam keadaan terurai. Masnamar (2007) menyatakan selain penyerapan hara melalui akar, daun juga mampu menyerap unsur hara sehingga pupuk cair bisa diberikan pada akar maupun daun tanaman. Agar bisa memberikan manfaat optimal bagi tanaman, dalam penggunaan pupuk organic cair harus dilakukan dengan tepat saat pemberian dan cara aplikasinya.

Pupuk blotong merupakan pupuk organic yang dibuat dari limbah pabrik gula. Blotong adalah limbah pabrik gula berbentuk padat seperti tanah berwarna hitam, mengandung air, dan memiliki bau tak sedap jika masih basah. Menurut Kuswuri (2009), diantara limbah pabrik gula yang lain, blotong merupakan limbah yang paling tinggi tingkat pencemarannya dan menjadi masalah bagi pabrik gula dan masyarakat. Dengan memanfaatkan blotong sebagai pupuk, akan membantu 


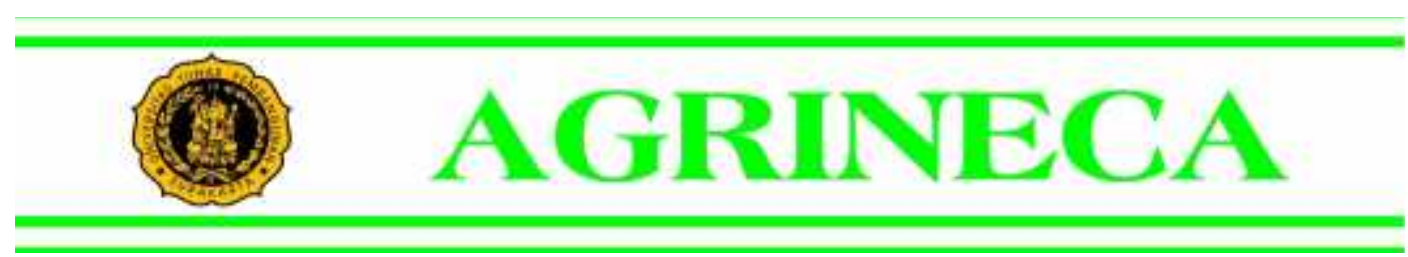

JURNAL ILMIAH AGRINECA

ISSN : 2721-074X (Online) - 2301-6698 (Print)

Available on : http://ejournal.utp.ac.id/index.php/AFP/index

This is Under CC BY SA Licence

mengurangi pencemaran lingkungan. Blotong masih banyak mengandung bahan organik, mineral, serat kasar, protein kasar ,dan gula ( Purwaningsih, 2011). Pupuk blotong dibuat melalui proses pengomposan. Komposisi pupuk blotong menurut Anonim (2012) yaitu pH 7,53; C $26,51 \% ; \mathrm{N} 1,04 \% ; \mathrm{C} / \mathrm{N} \quad 25,62 ; \mathrm{P} 2 \mathrm{O} 5$ 6,142\%; K2O 0,485\%; Na2O 0,082\%; Ca 5,785\%; $\mathrm{Mg}$ 0,419\%; Fe 0,191\%; $\mathrm{Mn}$ $0,115 \%$.

Pupuk Petroganik merupakan pupuk organic buatan pabrik yang banyak dijual di toko sarana pertanian (Ali, 2016). Pupuk Petroganik mempunyai keunggulan yaitu berbentuk butiran atau granul sehingga memudahkan petani dalam mengaplikasikan di lahannya, kadar Corganik tinggi, aman dan ramah lingkungan (bebas mikroba patogen), bebas dari biji-bijian gulma, kadar air rendah sehingga lebih efisien dalam pengangkutan dan penyimpanan, dan dikemas dalam kantong kedap air. Komposisi pupuk Petroganik kadar Corganik 15\%, C/N rasio 15-25, $\mathrm{pH} 4-8$ dan kadar air 8-12\%, berwarna coklat kehitaman dan berbentuk granul (Anonim, 2015).

Pupuk organic cair (POC) Nasa merupakan bahan organik murni berbentuk cair dari limbah ternak dan unggas, limbah alam dan tanaman yang diproses secara alamiah. POC Nasa berfungsi multiguna terutama dipergunakan untuk semua jenis tanaman pangan (padi, palawija, dll), hortikultura (sayuran, buah, bunga), dan tanaman tahunan (coklat, kelapa sawit) juga untuk ternak/unggas dan ikan/udang. Kandungan unsur hara mikro dalam 1 liter POC Nasa mempunyai fungsi setara dengan kandungan unsur hara mikro 1 ton pupuk kandang. Kandungan yang dimiliki POC Nasa berangsur-angsur akan memperbaiki konsistensi (kegemburan) tanah yang keras serta melarutkan SP-36 dengan cepat. POC Nasa juga mengandung hormon atau zat pengatur tumbuh (Auxin,
Giberelin, dan Sitokinin) yang bisa mempercepat perkecambahan biji, pertumbuhan akar, memperbanyak umbi, memperbanyak dan mengurangi kerontokan bunga dan buah. Aroma khas POC Nasa akan mengurangi serangan hama (Kardinan, A., 2011).

POC Nasa digunakan dengan cara disemprotkan pada bagian tanaman seperti bagian bawah daun, permukaan daun, ranting, dan batang tanaman hingga cukup basah (merata). Kandungan unsur hara dalam pupuk organik cair POC Nasa adalah $\mathrm{N} 0,12 \%, \mathrm{P} 2 \mathrm{O} 50,03 \%, \mathrm{~K} 2 \mathrm{O} \pm$ $0,18 \%, \mathrm{C}$ organik lebih dari $4 \% \mathrm{Zn} \mathrm{41,04}$ ppm, Cu 8,43 ppm, Mn 2,46 ppm, Co 2,54 ppm, Fe 0,45 ppm, S 0,12 \%, Ca 60,40 ppm, Mg 16,88 ppm, Cl 0,29\%, Na 0,15 $\%$, B 60,84 ppm, Si 0,01\%, Al 6,38 ppm, $\mathrm{NaCl} 0.98 \%$, Se 0,11 ppm, Cr < 0,06 ppm, Mo < 0,2 ppm, V < 0,04 ppm, So4 $0,35 \%, \mathrm{pH} 7,5, \mathrm{C} / \mathrm{N}$ ratio $0,86 \%$, Lemak $0,44 \%$, Protein $0,72 \%$ (Kardinan, A., 2011).

Berdasar uraian di atas, penulis tertarik untuk meneliti pengaruh penggunaan pupuk organic padat yaitu pupuk blotong dan Petroganik dan pupuk organic cair Nasa terhadap pertumbuhan dan hasil tanaman cabai rawit.

\section{METODE PENELITIAN}

\section{Tempat dan Waktu}

Penelitian ini dilaksanakan pada bulan Januari sampai Mei 2019 di Desa Bangsri, Kecamatan Karangpandan, Kabupaten Karanganyar dengan ketinggian tempat 450 meter diatas permukaan laut dengan jenis tanah Grumosol.

\section{Bahan dan Alat}

Bahan yang digunakan dalam penelitian ini yaitu : benih cabai rawit Pelita F1, tanah, pupuk Petroganik, pupuk Blotong, dan pupuk organik cair Nasa. 


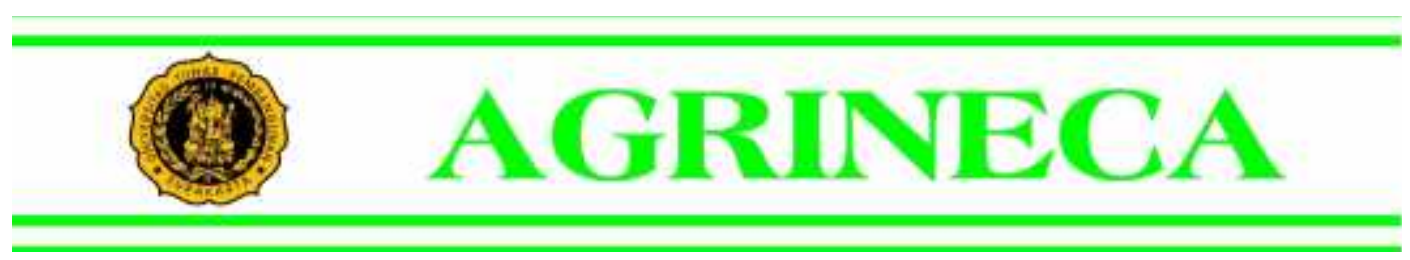

JURNAL ILMIAH AGRINECA

ISSN : 2721-074X (Online) - 2301-6698 (Print)

Available on : http://ejournal.utp.ac.id/index.php/AFP/index

This is Under CC BY SA Licence

Sedangkan alat terdiri dari rumah plastic, polibag (ukuran 50x50), ajir, cangkul, gembor, meteran, timbangan, alat tulis, cetok, penggaris, dan rafia.

\section{Rancangan Penelitian}

Penelitian ini menggunakan metode faktorial dengan rancangan dasar Rancangan Acak Lengkap (RAL) yang terdiri dari 2 faktor perlakuan dan diulang 3 kali,ditambah dengan sub ulangan sebanyak 2 kali. Factor pertama yaitu macam pupuk organic (M) terdiri dari 3 taraf, $\mathrm{M} 0=$ Tanah tanpa pupuk organik (kontrol), M1 = Tanah dan Pupuk Blotong ( 1:1), M2 = Tanah dan Pupuk Petroganik ( 1:1). Faktor kedua yaitu interval pemberian pupuk organik cair $(\mathrm{P})$ terdiri dari 3 taraf, $\mathrm{P} 0=$ Tanpa pemberian $\mathrm{POC}$ (pupuk organik cair) (kontrol), $\mathrm{P} 1=$ Pemberian POC setiap 7 hari sekali, P2 = Pemberian POC setiap 14 hari sekali.

\section{Tahap-tahap Penelitian}

1. Persiapan media tanam

Media disiapkan sesuai perlakuan, yang terdiri dari tanah saja, tanah dicampur dengan pupuk organic blotong, tanah dicampur pupuk Petroganik masing-masing dengan perbandingan volume $1: 1$, selanjutnya diisikan ke dalam polibag berukuran $50 \mathrm{~cm} \times 50 \mathrm{~cm}($ berat media $14,7 \mathrm{~kg}$ ).

\section{Penanaman}

Bibit tanaman yang sudah siap (berumur 2 minggu), dipindah tanam dari plastik pembibitan ke dalam media yang telah disiapkan kemudian dilakukan penyiraman.

3. Pemeliharaan

Pemeliharaan terdiri dari penyiraman, penyulaman, pemupukan, penyiangan, pemangkasan dan pengendalian hama penyakit.

a. Penyiraman dilakukan secara rutin setiap hari selama masa pertumbuhan tanaman sampai masa panen, pada pagi hari dengan menggunakan gembor.

b. Penyulaman dilakukan saat tanaman rusak atau mati. Batas waktu penyulaman adalah pada umur 2 minggu setelah tanam.

c. Pemupukan terdiri dari pupuk padat sesuai perlakuan (Petroganik dan Blotong) dilakukan diawal dicampurkan bersama tanah sebagai media tanam. Sedangkan pupuk organik cair Nasa diberikan sebagai pupuk tambahan sesuai perlakuan yaitu disemprotkan ke seluruh tubuh tanaman dengan interval sesuai perlakuan $(0,7$ hari, 14 hari sekali). Larutan POC dibuat dengan konsentrasi $2 \mathrm{ml}$ per liter air. Penyemprotan dilakukan pada sore hari.

d. Penyiangan dilakukan untuk mengendalikan gulma di sekitar tanaman agar tanaman dapat tumbuh dengan maksimal tanpa ada tanaman lain yang menyerap unsur hara yang dibutuhkan. Penyiangan dilakukan satu minggu sekali.

e. Pemangkasan dilakukan terhadap tunas muda dan pucuk batang. Tiap batang cukup ditinggalkan 2 cabang utama. Pemangkasan ini dilakukan pada saat tanaman berumur 45 hari setelah tanam. Pemangkasan dilakukan agar tanaman tumbuh dengan baik 
JURNAL ILMIAH AGRINECA

ISSN : 2721-074X (Online) - 2301-6698 (Print)

Available on : http://ejournal.utp.ac.id/index.php/AFP/index

This is Under CC BY SA Licence

dan maksimal pada 2 cabang utama yang telah disisakan.

4. Pengendalian hama dan penyakit dilakukan dalam bentuk pencegahan menggunakan pestisida asap cair, disemprotkan ke tanaman cabai seminggu sekali.

5. Panen

Panen dilakukan pada umur 100 hari setelah tanam, yaitu pada saat cabai rawit berwarna kemerahan. Panen dilakukan secara bertahap 3 hari sekali sebanyak 10 kali

\section{Pengamatan}

Pengamatan dilakukan terhadap parameter pertumbuhan meliputi tinggi tanaman, jumlah daun, berat brangkasan segar dan berat brangkasan kering, dan parameter hasil terdiri dari jumlah buah per tanaman, berat buah per tanaman, jumlah buah hijau per tanaman dan berat buah hijau per tanaman. Pengamatan buah hijau dilakukan saat panen terakhir.

\section{Analisis Data}

Data yang diperoleh dari hasil pengamatan dianalisis dengan sidik ragam (Anova). Jika berbeda nyata maka dilanjutkan dengan uji Duncan's Multiple Range Test (DMRT) untuk membedakan antar perlakuan.

\section{HASIL DAN PEMBAHASAN}

Penelitian ini merupakan percobaan dengan menggunakan polibag yang ditempatkan dalam rumah plastic berangka bambu, berukuran $10 \mathrm{~m} \times 5 \mathrm{~m}$, tinggi $2,5 \mathrm{~m}$. Plastik UV digunakan sebagai naungan. Arah rumah plastik barattimur. Jumlah total 54 unit tanaman dengan jarak antar polibag $30 \mathrm{~cm}$ x 30 $\mathrm{cm}$. Kondisi cuaca selama penelitian banyak hujan dan mendung.

Data hasil penelitian diolah dengan Anova (sidik ragam) yang hasilnya ditampilkan pada tabel

Tabel 1. Rangkuman hasil sidik ragam pengaruh macam pupuk organik dan interval pemberian pupuk cair terhadap pertumbuhan dan hasil cabai rawit.

\begin{tabular}{|c|c|c|c|c|c|c|}
\hline \multirow[t]{2}{*}{ No } & \multirow[t]{2}{*}{ Parameter } & \multicolumn{3}{|c|}{ Sumber keragaman } & \multicolumn{2}{|c|}{ Nilai } \\
\hline & & M & $\mathbf{P}$ & $\mathbf{M x P}$ & Tertinggi & Terendah \\
\hline 1. & $\begin{array}{l}\text { Tinggi tanaman } \\
(\mathrm{cm})\end{array}$ & $* *$ & $* *$ & ns & 105,17 (M2P2) & 59,50 (M0P0) \\
\hline 2. & Jumlah daun & $* *$ & $* *$ & ns & 30,17 (M2P2) & $13,50(\mathrm{M} 0 \mathrm{P} 0)$ \\
\hline 3. & $\begin{array}{l}\text { Berat brangkasan } \\
\text { segar }(\mathrm{g})\end{array}$ & $* *$ & $* *$ & $* *$ & $249,50(\mathrm{M} 2 \mathrm{P} 2)$ & $103,50(\mathrm{M} 0 \mathrm{P} 0)$ \\
\hline 4. & $\begin{array}{l}\text { Berat brangkasan } \\
\text { Kering }(\mathrm{g})\end{array}$ & $* *$ & $* *$ & ns & 30,67 (M2P2) & 16,67 (M0P0) \\
\hline 5. & Jumlah buah (g) & $* *$ & $* *$ & $* *$ & 24,83 (M2P2) & 4,17 (M0P0) \\
\hline 6. & Berat buah (g) & $* *$ & $* *$ & $* *$ & 49,83 (M2P2) & 8,67 (M0P0) \\
\hline 7. & $\begin{array}{l}\text { Jumlah buah hijau } \\
\text { (g) }\end{array}$ & $* *$ & $* *$ & ns & $9,33(\mathrm{M} 2 \mathrm{P} 2)$ & 1,33 (M0P0) \\
\hline 8. & Berat buah hjau & $* *$ & $* *$ & ns & 18,83 (M0P0) & 2,67 (M0P0) \\
\hline
\end{tabular}
(g)

Sumber: Analisis data primer, 2019

Keterangan :** berpengaruh sangat nyata, ns tidak signifikan

Dari hasil sidik ragam dapat diketahui bahwa perlakuan macam pupuk organik (M) dan interval pemberian pupuk organik cair Nasa $(\mathrm{P})$ berpengaruh sangat 


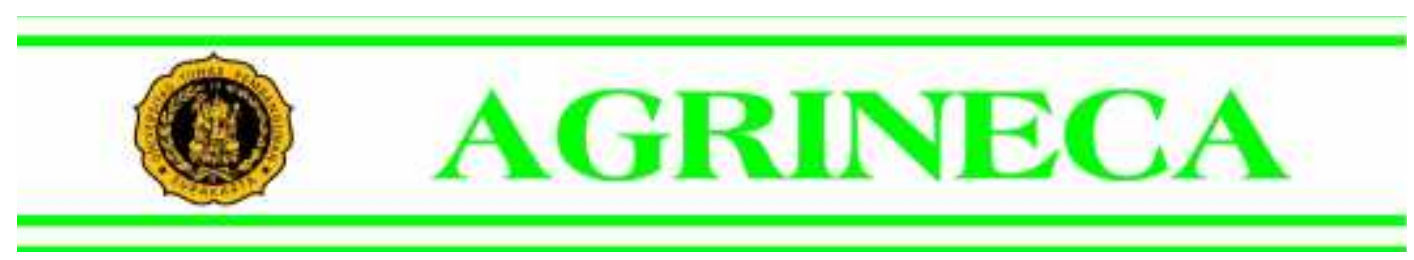

JURNAL ILMIAH AGRINECA

ISSN : 2721-074X (Online) - 2301-6698 (Print)

Available on : http://ejournal.utp.ac.id/index.php/AFP/index

This is Under CC BY SA Licence

Keterangan: perlakuan yang diikuti huruf sama pada kolom yang sama menunjukkan tidak berbeda nyata pada uji lanjut Duncan $(\alpha 5 \%)$

menambah unsur hara, juga dapat memperbaiki struktur tanah, meningkatkan kapasitas tukar kation, meningkatkan kemampuan menahan air dan meningkatkan kegiatan biologi tanah.

Pengaruh pemberian pupuk organik yang mampu meningkatkan kemampuan menyimpan air , menyebabkan kandungan air tanaman lebih banyak sehingga berat brangkasan segar tanaman cabai dengan media tanam yang menggunakan pupuk organic menjadi lebih tinggi. Hal ini terlihat dari berat brangkasan segar pada perlakuan M2 dan M1 lebih tinggi dibanding M0.

Dengan penambahan pupuk organik yang mampu memperbaiki sifat fisik,kimia dan biologi tanah yang lebih baik maka tanaman juga bisa melangsungkan proses fotosintesa dengan lebih baik dan menyimpan hasil fotosintat yang lebih besar sehingga meningkatkan berat brangkasan kering tanaman. Berat brangkasan kering perlakuan M2 dan M1 lebih tinggi dibanding M0.

Pertumbuhan tanaman cabai rawit yang tidak berbeda nyata antara yang diberi pupuk organik blotong dan Petroganik, menunjukkan bahwa meskipun komposisi kedua macam pupuk terdapat perbedaan, namun memberikan dampak sama dalam mendukung pertumbuhan tanaman.

Dari tabel 2 dapat diketahui bahwa ada pengaruh nyata penambahan pupuk organik cair terhadap petumbuhan tanaman sehingga tinggi tanaman, jumlah daun, brangkasan segar dan kering pada perlakuan P1 (pemberian POC 7 hari sekali) dan P2 (pemberian POC 14 hari sekali) lebih tinggi dan berbeda nyata dibanding yang tanpa pemberian POC (P0). Sebagaimana dikemukakan Kardinan, A. (2011), POC Nasa selain mengandung unsur makro dan mikro, juga mengandung hormon pertumbuhan yang mampu menstimulir pembentukan organ-organ tanaman. Namun antara pemberian POC 7 hari sekali dan 14 hari sekali mempunyai kecenderungan tidak memberikan pengaruh berbeda nyata terhadap pertumbuhan tanaman. Hal ini diduga ada batas maksimum tanaman melalui permukaan daun dan cabang tanaman dalam menyerap unsur hara.

Dari tabel 2 dapat diketahui pula bahwa tidak ada beda nyata pengaruh interaksi kedua perlakuan $\left(\begin{array}{lll}M & \mathrm{x} & \mathrm{P}\end{array}\right)$ terhadap tinggi tanaman, jumlah daun dan berat brangkasan kering, artinya diantara kedua perlakuan tidak ada saling mempengaruhi terhadap parameterparameter tersebut, tetapi ada pengaruh interaksi kedua perlakuan pada brangkasan segar tanaman. Hal ini diduga karena faktor pengaruh kemampuan pupuk organik dalam menyimpan air sehingga menghasilkan berat brangkasan segar yang lebih tinggi.

Tidak ada beda nyata berat brangkasan segar antar perlakuan media tanpa pupuk organic yang dikombinasi dengan penambahan POC baik yang interval 7 hari sekali maupun 14 hari sekali (M0P0, M0P1, M0P2). Sedangkan pada media tanam dengan penambahan pupuk organic blotong maupun Petroganik, yang dikombinasi dengan POC dengan interval 7 dan 14 hari sekali saling berbeda nyata, dan nampak bahwa yang dikombinasi dengan POC menghasilkan brangkasan segar yang lebih tinggi. Hal ini menunjukkan adanya pengaruh interaksi yang positif antara pupuk organic padat (blotong maupun Petroganik) dan pemberian POC Nasa. . Dengan adanya penambahan pupuk organik cair bisa menambah unsur hara yang bisa terserap tanaman sehingga mendukung pertumbuhan tanaman. Hal ini terlihat pada semua parameter pertumbuhan dimana angka yang dicapai pada perlakuan yang tanpa adanya 


\section{JURNAL ILMIAH AGRINECA \\ ISSN : 2721-074X (Online) - 2301-6698 (Print) \\ Available on : http://ejournal.utp.ac.id/index.php/AFP/index \\ This is Under CC BY SA Licence}

penambahan POC, lebih rendah dibanding yang disertai penambahan POC. Tanaman cabai rawit bisa tumbuh lebih baik dengan penambahan pupuk organik padat berupa pupuk blotong atau Petroganik yang dicampurkan pada media tanah, disertai pemberian pupuk organic cair Nasa sebagai pupuk tambahan yang diberikan melalui tubuh tanaman.

\section{Hasil Tanaman}

Hasil uji Duncan pengaruh macam pupuk organik dan interval pemberian pupuk organik cair Nasa terhadap hasil cabai rawit disajikan pada tabel 3 .

Tabel 3. Hasil Uji Jarak Berganda Duncan Pengaruh Dosis Pupuk Kandang Sapi dan Mikoriza Terhadap Hasil Tanaman Kedelai

\begin{tabular}{|c|c|c|c|c|}
\hline \multirow[b]{2}{*}{ Perlakuan } & \multicolumn{4}{|c|}{ Parameter hasil } \\
\hline & $\begin{array}{c}\text { Jumlah buah per } \\
\text { tanaman }\end{array}$ & $\begin{array}{l}\text { Berat buah per } \\
\text { tanaman }(\mathrm{g})\end{array}$ & $\begin{array}{c}\text { Jumlah buah hijau } \\
\text { per tanaman }\end{array}$ & $\begin{array}{l}\text { Berat buah hijau } \\
\text { per tanaman (g) }\end{array}$ \\
\hline \multicolumn{5}{|c|}{ Macam pupuk organik (M) } \\
\hline M0 & $6,11 \mathrm{a}$ & $12,22 \mathrm{a}$ & 3,67 a & 7,33 a \\
\hline M1 & $36,67 \mathrm{~b}$ & $73,33 \mathrm{~b}$ & $14,67 \mathrm{~b}$ & $29,33 \mathrm{~b}$ \\
\hline M2 & $40,11 \mathrm{~b}$ & $80,22 \mathrm{~b}$ & $15,89 \mathrm{~b}$ & $31,78 \mathrm{~b}$ \\
\hline \multicolumn{5}{|c|}{ Interval pemberian pupuk organik cair $(\mathrm{P})$} \\
\hline $\mathrm{P} 0$ & 18,78 a & 37,56 a & 9,33 a & 18,67 a \\
\hline $\mathrm{P} 1$ & $26,33 \mathrm{~b}$ & $52,67 \mathrm{~b}$ & 11,33 a & 22,67 a \\
\hline $\mathrm{P} 2$ & $37,78 \mathrm{~b}$ & $75,56 \mathrm{~b}$ & 13,56 a & $27,11 \mathrm{a}$ \\
\hline \multicolumn{5}{|c|}{ Kombinasi macam pupuk organik dan interval pemberian pupuk organik cair $(\mathrm{MxP})$} \\
\hline MOP0 & 5,33 a & 10,67 a & 3,00 & 6,00 \\
\hline M0P1 & 6,00 a & 12,00 a & 3,67 & 7,33 \\
\hline M0P2 & 7,00 a & 14,00 a & 4,33 & 8,67 \\
\hline M1P0 & $24,33 \quad b$ & $48,67 \mathrm{~b}$ & 11,67 & 23,33 \\
\hline M1P1 & $36,00 \mathrm{bc}$ & $72,00 \mathrm{bc}$ & 14,67 & 29,33 \\
\hline M1P2 & $49,67 \mathrm{~cd}$ & $99,33 \mathrm{~cd}$ & 17,67 & 35,33 \\
\hline $\mathrm{M} 2 \mathrm{P} 0$ & $26,67 \quad b$ & $53,33 \mathrm{~b}$ & 13,33 & 26,67 \\
\hline M2P1 & $37,00 \quad b c$ & $74,00 \quad \mathrm{c}$ & 15,67 & 31,33 \\
\hline M2P2 & $56,67 \mathrm{~d}$ & $113,33 \mathrm{~d}$ & 18,67 & 37,33 \\
\hline
\end{tabular}

Sumber : Analisis data primer, 2019

Keterangan: perlakuan yang diikuti huruf sama pada kolom yang sama menunjukkan tidak berbeda nyata pada uji lanjut Duncan $(\alpha 5 \%)$

Dari hasil uji Duncan (tabel 3) diketahui bahwa secara factor tunggal, perlakuan media tanpa penambahan pupuk organic (M0) berbeda nyata dengan perlakuan media yang diberi campuran pupuk organic baik pupuk blotong (M1) maupun pupuk petroganik (M2) pada semua parameter hasil sedangkan antara perlakuan M1 dan M2 tidak berbeda nyata pada semua parameter hasil.
Jumlah buah dan berat buah per tanaman pada tanaman cabai rawit dengan media M0 paling rendah dibanding M1 dan M2. Hal ini dikarenakan kandungan unsur hara pada perlakuan M0 paling rendah hanya berupa tanah tanpa penambahan pupuk organik. Penambahan pupuk organik selain menambah unsur hara, juga mampu memperbaiki sifat fisik tanah menjadi lebih gembur dan kemampuan menyimpan air yang lebih besar pula. 


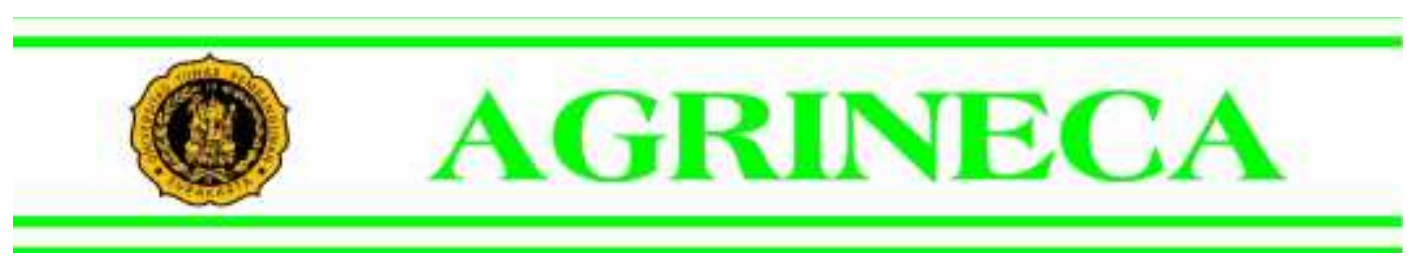

JURNAL ILMIAH AGRINECA

ISSN : 2721-074X (Online) - 2301-6698 (Print)

Available on : http://ejournal.utp.ac.id/index.php/AFP/index

This is Under CC BY SA Licence

Kombinasi perlakuan pupuk organic Petroganik atau blotong dan POC dengan interval 14 hari sekali menghasilkan jumlah buah dan berat buah per tanaman lebih tinggi dibanding yang ditambah POC 7 hari sekali. Dengan interval pemberian $\mathrm{POC}$ yang lebih sering ( 7 hari sekali) sebetulnya tanaman mendapatkan lebih banyak unsur-unsur yang berguna bagi tanaman, tetapi hasilnya justeru lebih rendah dibanding yang interval 14 hari sekali. Hal ini kemungkinan karena tanaman memerlukan proses dalam menyerap unsure hara melalui tubuh tanaman (daun, cabang, ranting) dan juga ada batas kemampuan stomata dan kutikula dalam menyerap unsur hara sehingga interval 14 hari lebih efektif dibanding interval 7 hari.

Hasil yang berbeda didapati pada pakchoy dimana interval pemberian POC Nasa 5 hari sekali tidak berbeda nyata dengan interval 10 hari sekali terhadap hasil tanaman pakchoy dalam polibag (Daryanti dan Tyas Soemarah K.D, 2017). Hal ini diduga karena kebutuhan unsur hara kemungkinan sudah tercukupi dari media tanam yang diberi tambahan pupuk organik padat sehingga pengaruh pemberian POC Nasa dengan interval yag berbeda tidak berpengaruh terhadap hasil tanaman.

Pada penelitian ini nampak bahwa perlakuan kombinasi penggunaan pupuk organic baik blotong atau Petroganik dengan disertai pemberian POC Nasa 14 hari sekali menghasilakn jumlah dan berat buah yang paling tinggi.

\section{KESIMPULAN}

Dari penelitian ini dapat diambil kesimpulan perlakuan macam pupuk organic dan interval pemberian POC berpengaruh sangat nyata terhadap pertumbuhan tanaman ( tinggi tanaman, jumlah daun, berat brangkasan segar dan brangkasan kering) maupun hasil tanaman cabai rawit (jumlah buah per tanaman, berat buah per tanaman, jumlah dan berat buah hijau per tanaman).

Interaksi antara perlakuan macam pupuk organic dan interval pemberian POC tidak berpengaruh nyata terhadap tinggi tanaman, jumlah daun dan berat brangkasan kering, berpengaruh sangat nyata pada jumlah buah, berat buah per tanaman, tetapi tidak berpengaruh nyata terhadap jumlah dan berat buah hijau per tanaman.

Kombinasi penggunaan pupuk organic baik blotong atau Petroganik yang dicampurkan dengan tanah dengan rasio 1:1, disertai dengan pemberian POC Nasa 14 hari sekali menghasilkan jumlah dan berat buah yang paling tinggi.

\section{DAFTAR PUSTAKA}

Anonim. 2012. www.omtani.com Mekanisme Pupuk Organik dalam Menyediakan Unsur Hara bagi Tanaman. Diakses pada tanggal 28 Oktober 2015. Jam 19.35

Anonim. 2015.Manfaat, Keunggulan, dan Spesifikasi Petroganik. Petrokimia Gresik. Gresik.

Anonim. 2019. www.pertanian.go.id Produksi Tanaman Cabai Rawit Menurut Provinsi, 2014-2018.Kementrian Pertanian Republik Indonesia. Jakarta

Ali, M. (2016). Pembuatan PGPR (Plant Growth Promoting Rhizobacteria) Dari Akar Bambu. Development of Agriculture, 2(1), 1-12.

Ali, M., Hosir, A., \& Nurlina, N. (2017). PERBEDAAN JUMLAH BIBIT PER LUBANG TANAM TERHADAP PERTUMBUHAN DAN HASIL TANAMAN PADI (Oryza sativa L.) DENGAN MENGGUNAKAN METODE SRI. Gontor AGROTECH Science Journal, 3(1), 1-21.

Chairani. 2005. Pengaruh Pemberian Pupuk Organik Blotong dan Pupuk Sulfomag Plus Terhadap Sifat Kimia Tanah, Pertumbuhan, dan Produksi Tanaman Jagung (Zea mays) pada Tanah Typic Pelaudult. Fakultas Pertanian UISU Medan. 
JURNAL ILMIAH AGRINECA

ISSN : 2721-074X (Online) - 2301-6698 (Print)

Available on : http://ejournal.utp.ac.id/index.php/AFP/index

This is Under CC BY SA Licence

Daryanti dan Tyas Soemarah K.D. 2017. Pengaruh Berat Media Dan Interval Pemberian Pupuk Cair Terhadap Pertumbuhan Dan Hasil Tanaman Pakchoy Dalam Polibag. Agrineca Vol. 17 No. 2 Juli 2017.

Djuniarty, M.D. 2016. Pemanfaatan Bokashi Blotong Pada Pertumbuhan dan Hasil Bawang merah. Jurnal Ilmiah Agrotech. Vol. I No. 1 Agustus 2016 (9-17).

Hardjowigeno, S. 2010. Ilmu Tanah. Akademik Pressindo. Jakarta.

Kardinan, A. 2011. Pupuk Organik Cair Nasa. POC NASA.com, Februari, 2011.

Medaang, E.S. , Puji, A. 2016. Pengaruh Pemberian Pupuk Organik Cair Nasa dan Pupuk Kandang ayam Terhadap Pertumbuhan dan Produksi Tanaman
Selada. Jurnal Agrifor Volume XV No. 1 Maret 2016.

Musnamar, E.I. 2007. Pupuk Organik : Cair dan Padat, Pembuatan, Aplikasi. Penebar Swadaya. Jakarta.

Purwaningsih, E. 2011. Pengaruh Pemberian Kompos Blotong. Legin, dan Mikoriza Serapan Hara N dan P Tanaman Kacang Tanah. Widya Warta No 02 Tahun XXXV.

Sulistio, A., Hery, S., Marisi, N. 2018. Pengaruh Pupuk Petroganik dan Pupuk Growmore Terhadap Pertumbuhan dan Hasil Tanaman Cabai Rawit. Jurnal Agrifor vol VVII No. 1 Maret 2018.

Sutedjo, M. M. 2010. Pupuk dan Cara Pemupukan. Rineka Cipta. Jakarta. 


\section{AGRINECA}

JURNAL ILMIAH AGRINECA

ISSN : 2721-074X (Online) - 2301-6698 (Print)

Available on : http://ejournal.utp.ac.id/index.php/AFP/index

This is Under CC BY SA Licence 